\title{
THE CHANGE OF WATER VAPOUR RESISTANCE OF MATERIALS USED FOR THE CLOTHING PRODUCTION DURING EXPLOITATION
}

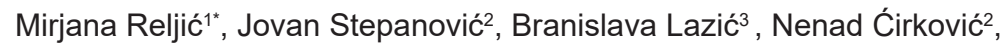 \\ Dragana Cerović ${ }^{3}$
}

(ORIGINAL SCIENTIFIC PAPER)

${ }^{1}$ Cis Institute, Belgrade, Serbia

${ }^{2}$ Faculty of Technology, University of Niš, Leskovac, Serbia

${ }^{3}$ The College of Textile - Design, Technology and Management, Belgrade, Serbia

The aim of the paper was to test the changes of thermo-physiological properties of fabrics occuring during the clothing maintenance, i.e. washing. Hot plate measurements were used. The test results were not observed separately but in terms of interrelatedness of the material properties. The obtained results show that certain yarn properties have a substantial impact on the change of water vapour resistance of the fabrics (Ret), and were used to establish a mathematical model for predicting thermophysiological comfort of woven structures while being used, i.e. cared for. The conducted research enabled the description, classification and definition of the elements of relatedness of fabric parameters with thermophysiological properties of a cloting item, based on which the comfort parameters of similar fabrics, as well as the usage properties of the products made of them can be predicted.

Keywords: textile materials, water vapour resistance, hot plate, thermal comfort clothing

\section{Introduction}

The production of textile materials for special-purpose and good thermal comfort clothing is a great challenge nowadays for many manufacturers of fibers, yarns and textile fabrics (woven, knitted, nonwoven). Any kind of human physical activity will create the need for releasing the excessive heat with a view of maintaining a stable body temperature [1]. These fabrics are usually used to make windproof garments, typically produced in multi-layered forms to enhance warmth and comfort under windy and cold conditions [2]. Apart from achieving the needed thermal comfort, it is particularly important to prolong the garment life, that is, to produce clothing ensembles (items) the thermal comfort of which will not significantly change during its usage, i.e. maintenance. For effective use of clothing, it is important to predict the period after which certain functional properties will be lost due to maintenance (thermal comfort in this case).

Since one of the thermal comfort parameters is water vapour permeability ("breathability") of a garment, the authors of this paper investigated the change of the water vapour resistance (Ret) during maintenance (washing) in order to establish its functional dependence on the number of washing cycles. That would enable the prediction of the behaviour of a clothing ensemble during its usage, that is, the determination of its life for a specific purpose.

The research tested four fabrics used in the production of special-purpose clothing ensembles (for specific conditions of usage) in which certain thermophysiological properties have to be achieved with the aim of maintaining thermal comfort of a consumer. The clothing made of materials having high-thermal insulation is essential for thermal protection, but it typically entails the increased bulkiness of the clothing which significantly limits the human performance, and even introduces discomfort and fatigue due to the increased physical strains over time while moving in heavy and bulky garments [3].

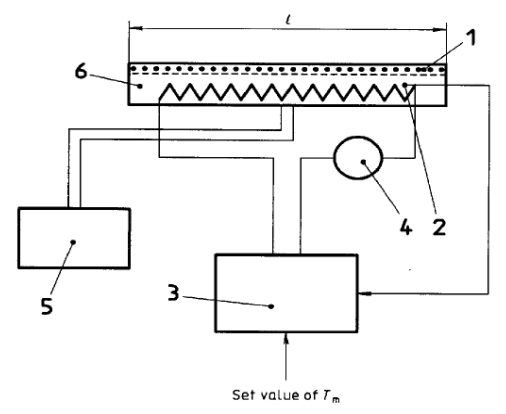

Figure 1. Measuring unit with temperature and water supply control: 1. metal plate; 2. temperature sensor; 3. temperature controller; 4. heating-power measuring device; 5 . water-dosing device and 6. metal block with heating element

\footnotetext{
*Author address: Reljić Mirjana, Cis Institute,

Vojislava Ilića 88, 11000 Belgrade, Serbia

E-mail: reljicmira@gmail.com

The manuscript received: August, 16, 2016.

Paper accepted: October, 12, 2016.
} 
A hot plate (Figure 1) simulates processes which occur along human skin. During the water vapour resistance test, the power required to maintain the plate temperature at $35^{\circ} \mathrm{C}$ is being measured. Water is supplied to the surface of a porous plate (1 in Figure 1) by a dosing device (5 in Figure 1), such as a motor-driven burette. The dosing device is activated by a switch which senses when the level of water in the plate falls more than $1 \mathrm{~mm}$ below the plate surface in order to maintain a constant rate of evaporation. The level switch is mechanically connected to the measuring unit. Before entering the measuring unit, the water shall be preheated to the temperature of the measuring unit. This can be achieved by passing it through the tubes in the thermal guard, before it enters the measuring unit. The water vapour resistance of the fabric is expressed in units $\mathrm{m}^{2}$ $\mathrm{Pa} / \mathrm{W}$. International standard ISO 11092:2014 - Textile - Physiological influences - Measurement of thermal resistance and water vapour resistance under steadystate conditions (sweating guarded hotplate test) defines the method for measuring the water vapour resistance under steady-state conditions of fabrics, films, coatings, foamed materials and leather, multilayer assemblies used for the production of clothing, quilts, sleeping bags, upholstery and similar textile and textile-like products [4].

The application of this measurement technique is restricted to the maximum water vapour resistance, which depends on dimensions and the construction of the apparatus used. The test is carried out at the temperature
$\mathrm{T}=35^{\circ} \mathrm{C}$, air flow velocity $\mathrm{v}=1,0 \mathrm{~m} \cdot \mathrm{s}^{-1}$ and relative air humidity $\mathrm{RH}=40 \%$. The test sample is placed on an electrically heated plate with conditioned air ducted to flow across and parallel to its upper surface.

For the determination of the water vapour resistance, an electrically heated porous plate is covered by a water vapour permeable but liquid water impermeable membrane. Water feeds the heated plate with the vapour which passes through the membrane so that no liquid water contacts the test sample. When the test sample is placed on the membrane, the heat flux required to maintain the hotplate temperature is a measure of the rate of water evaporation, and from this the water vapour resistance of the test sample is determined.

The technique described in this International Standard enables the water vapour resistance Ret of a material to be determined by subtracting the water vapour resistance of the boundary air layer above the surface of the test apparatus from that of a test sample, both measured under the same conditions. The advantages of the hotplate test method are: easy execution, easy handling, quick individual measurement and good repeatability of the measurement.

The Hohenstein Institute from Germany carried out the classification, i.e. ranking system of Ret values (Table 1) [5]. According to it, based on the measured water vapour resistance, the comfort, i.e. thermal comfort of the garment while in use can be predicted.

Table 1. Ret comfort rating system [5]

\begin{tabular}{lcl}
\hline Rating & Ret value & Description \\
\hline Very good & $0-6$ & Extremely breathable and comfortable at a higher level of activity \\
Good & $7-13$ & $\begin{array}{l}\text { Very breathable and comfortable at a moderate rate of activity } \\
\text { Satisfactory }\end{array}$ \\
$\begin{array}{l}\text { Unsatisfactory } \\
\text { Breathable, but uncomfortable at a higher rate of activity }\end{array}$ \\
$\begin{array}{l}\text { Very } \\
\text { unsatisfactory }\end{array}$ & $31-30$ & $\begin{array}{l}\text { Slightly breathable, giving moderate comfort at a low rate of } \\
\text { activity }\end{array}$ \\
\hline
\end{tabular}

Table 2. Types of applied fabrics

\begin{tabular}{ll}
\hline $\begin{array}{l}\text { Fabric } \\
\text { designation }\end{array}$ & Manufacturing product name \\
\hline Sample 1 & $\begin{array}{l}\text { Basic material 100\% PES (without membrane and coating) } \\
\text { Sample 2 }\end{array}$ \\
$\begin{array}{l}\text { Sample 3 } \\
\text { Sample 4 }\end{array}$ & $\begin{array}{l}100 \% \text { PES with PTFE membrane (white coating) } \\
\text { the fleece is a one-side ragged knitted fabric from } 100 \% \text { PES }\end{array}$ \\
\hline
\end{tabular}

\section{Experimental}

The experimental part was carried out in CIS Institute (Belgrade, Serbia). Both standardised and unstandardised methods were used for identifying and testing the quality of yarns, fabrics and the methods of thermophysiological analysis of a clothing system on the hotplate. Also, adequate methods of mathematical processing of experimental results were used.
The research included tests of:

- $\quad$ PES filament yarn parameters (art. CONCORDIA TEXTILES 70/29/1), used for the production of fabrics for special-purpose clothing;

- $\quad$ properties of four fabrics (of which the fabric of $100 \%$ PES without the membrane and coating in textile weaves is used as a basis for manufacturing the remaining three fabrics - Table 2);

- the change of water vapour resistance proper- 
ties expressed through Ret values during fabrics maintenance or washing (up to 50 washing cycles).

The methods applied in the test are stated in the Table with the test results.

Establishing the mathematical model of Ret values dependence on the number of washing cycles

For determining the dependence of Ret values of the tested textile materials on the number of washing cycles, the adequate mathematical model has been proposed. In order to illustrate a non-linear regression model, a polynomial model is presented, as it is much simpler than the modified gradational model. Generally, both methods use the same method of error minimizing [6,7].

For the given string of data pairs $\left(x_{1}, y_{1}\right),\left(x_{2}, y_{2}\right), \ldots,\left(x_{n}, y_{n}\right)$, the dependence of the form

$y=a_{0}+a_{1} x+\ldots+a_{m} x^{m}$ has to be determined, where $m \leq n-2$, so as to illustrate the experimental data in the best possible way.

As a quality measure of fitting the experimental data obtained by the empirical formula, mean square deviation (S) of the formula from the experimental values is used and it is defined as:

$S=\frac{\sum_{i=1}^{n} E_{i}^{2}}{n-(m+1)}=\frac{\sum_{i=1}^{n}\left(y_{i}-f\left(x_{i}\right)\right)^{2}}{n-(m+1)}$

where:

$f\left(x_{i}\right)$ - the value of approximated function in every point, $n-(m+1)-$ the value representing number of freedom degrees defined as the difference between the number of experimental points and the total number of parameters $a_{0}, a_{1}, \ldots, a_{m}$.

The smaller the value $\mathrm{S}$, the better the empirical formula fits experimental data.

Table 3. Properties of PES filament yarns

\begin{tabular}{lll}
\hline Performance tested & Method used & Value Obtained \\
\hline Material composition [\%] & ISO 1833-1:2006 [9] & $100 \%$ PES \\
Yarn Count [tex] & SRPS EN ISO 2060:2012 [10] & $\begin{array}{l}\text { for warp: } 8.3 \\
\text { for weft: 8.4 }\end{array}$ \\
& & for warp: 110-115 \\
Number of turns in yarns [m-1] & SRPS ISO 2061:2012 [11] & for weft: without turns \\
\hline
\end{tabular}

Table 4. Breakdown of properties of tested fabrics

\begin{tabular}{|c|c|c|c|c|}
\hline $\begin{array}{l}\text { Performance tested and } \\
\text { the method used }\end{array}$ & Sample 1 & Sample 2 & Sample 3 & Sample 4 \\
\hline $\begin{array}{l}\text { Material composition } \\
\text { ISO 1833-24:2010 [12] }\end{array}$ & $100 \%$ PES & $\begin{array}{l}100 \% \text { PES } \\
\text { with PTFE } \\
\text { membrane }\end{array}$ & $\begin{array}{l}100 \% \text { PES } \\
\text { with PU } \\
\text { membrane }\end{array}$ & $\begin{array}{l}100 \% \text { PES three- } \\
\text { layers fabric with } \\
\text { PU coating and } \\
\text { fleece }\end{array}$ \\
\hline $\begin{array}{l}\text { Longitudinal mass } \\
\left.\text { [g.m }{ }^{-2}\right] \\
\text { ISO } 3801: 1977[13]\end{array}$ & 107.3 & 138.5 & 169.0 & 205.6 \\
\hline $\begin{array}{l}\text { Thickness [mm] } \\
\text { ISO 5084:1996 [14] } \\
\text { Density of threads }\left[\mathrm{cm}^{-1}\right]\end{array}$ & 0.18 & 0.21 & 0.21 & 0.38 \\
\hline $\begin{array}{l}\text {-warp } \\
\text {-weft } \\
\text { ISO 7211-2:1984 [15] } \\
\text { Fineness [tex] }\end{array}$ & $\begin{array}{l}69.0 \\
47.6\end{array}$ & $\begin{array}{l}70.0 \\
48,3\end{array}$ & $\begin{array}{l}68.0 \\
46.0\end{array}$ & $\begin{array}{l}68.0 \\
47.3\end{array}$ \\
\hline $\begin{array}{c}\text { - for warp } \\
\text { - for weft } \\
\text { SRPS ISO:2060:2012 [10] }\end{array}$ & $\begin{array}{l}8.5 \\
8.5\end{array}$ & $\begin{array}{l}8,7 \\
9.2\end{array}$ & $\begin{array}{l}8.7 \\
9.3\end{array}$ & $\begin{array}{l}8.6 \\
8.9\end{array}$ \\
\hline
\end{tabular}

Table 5. Changes of the surface mass of fabrics at a different number of washing cycles

\begin{tabular}{|c|c|c|c|c|c|c|c|c|c|c|c|}
\hline \multirow[b]{2}{*}{ Fabric } & \multicolumn{11}{|c|}{ Surface mass of fabric $\left[\mathrm{g} \cdot \mathrm{m}^{-2}\right]$} \\
\hline & Untreated & $\begin{array}{c}\text { After } 5 \\
\text { washings }\end{array}$ & $\begin{array}{c}\text { After } 10 \\
\text { washings }\end{array}$ & $\begin{array}{c}\text { After } 15 \\
\text { washings }\end{array}$ & $\begin{array}{c}\text { After } 20 \\
\text { washings }\end{array}$ & $\begin{array}{c}\text { After } 25 \\
\text { washings }\end{array}$ & $\begin{array}{l}\text { After } 30 \\
\text { washings }\end{array}$ & $\begin{array}{c}\text { After } 35 \\
\text { washings }\end{array}$ & $\begin{array}{c}\text { After } 40 \\
\text { washings }\end{array}$ & $\begin{array}{c}\text { After } 45 \\
\text { washings }\end{array}$ & $\begin{array}{c}\text { After } 50 \\
\text { washings }\end{array}$ \\
\hline Sample 1 & 107.3 & 107.0 & 107.0 & 106.8 & 106.6 & 106.5 & 106.3 & 106.1 & 106.0 & 105.9 & 105.9 \\
\hline Sample 2 & 138.5 & 137.7 & 137.2 & 136.7 & 136.8 & 136.8 & 136.4 & 136.5 & 136.5 & 136.2 & 136.0 \\
\hline Sample 3 & 169.0 & 169.0 & 168.9 & 168.5 & 168.6 & 168.3 & 167.7 & 167.5 & 167.2 & 167.2 & 166.8 \\
\hline Sample 4 & 205.6 & 205.4 & 205.1 & 204.7 & 204.5 & 204.1 & 204.1 & 203.9 & 203.6 & 203.5 & 203.1 \\
\hline
\end{tabular}

Table 6. Changes of water vapour resistance of fabrics Ret $\left(\mathrm{m}^{2} \mathrm{~Pa} / \mathrm{W}\right)$ at a different number of washing cycles $\left(T=35^{\circ} \mathrm{C} ; \mathrm{v}=\right.$ $\left.1,0 \mathrm{~m} \cdot \mathrm{s}^{-1} ; \mathrm{RH}=40 \%[4]\right)$

\begin{tabular}{cccccccccccc}
\hline Fabric & Untreated & $\begin{array}{c}\text { After 5 } \\
\text { washings }\end{array}$ & $\begin{array}{c}\text { After 10 } \\
\text { washings }\end{array}$ & $\begin{array}{c}\text { After 15 } \\
\text { washings }\end{array}$ & $\begin{array}{c}\text { After 20 } \\
\text { washings }\end{array}$ & $\begin{array}{c}\text { After 25 } \\
\text { washings }\end{array}$ & $\begin{array}{c}\text { After 30 } \\
\text { washings }\end{array}$ & $\begin{array}{c}\text { After 35 } \\
\text { washings }\end{array}$ & $\begin{array}{c}\text { After 40 } \\
\text { washings }\end{array}$ & $\begin{array}{c}\text { After 45 } \\
\text { washings }\end{array}$ & $\begin{array}{c}\text { After 50 } \\
\text { washings }\end{array}$ \\
\hline Sample 1 & 4.44 & 5.09 & 5.16 & 5.34 & 6.44 & 6.58 & 6.68 & 6.71 & 6.83 \\
Sample 2 & 4.86 & 5.35 & 5.64 & 5.89 & 6.93 & 7.91 & 8.04 & 8.07 & 8.98 & 9.10 & 10.73 \\
Sample 3 & 19.55 & 20.36 & 20.44 & 20.68 & 21.74 & 21.65 & 22.07 & 22.32 & 23.22 & 24.37 & 25.148 \\
Sample 4 & 27.28 & 27.89 & 28.06 & 28.23 & 29.42 & 29.61 & 30.79 & 30.95 & 31.16 & 32.35 & 33.51 \\
\hline
\end{tabular}


Table 7. Breakdown of calculated coefficients of the empirical formula (2) and breakdown of mean square deviation values according to formula (1)

\begin{tabular}{|c|c|c|c|c|}
\hline \multirow{2}{*}{ Fabric } & \multicolumn{3}{|c|}{ Coefficients of the empirical formula (3) } & \multirow{2}{*}{$\begin{array}{l}\text { Mean square deviation values } \\
\text { according to formula (2) }\end{array}$} \\
\hline & a & $b$ & c & \\
\hline Sample 1 & 4.12620 & 0.309860 & 0.607130 & 0.084021 \\
\hline Sample 2 & 4.67580 & 0.124750 & 0.095373 & 0.095832 \\
\hline Sample 3 & 20.0250 & 0.000900 & 2.224400 & 0.096449 \\
\hline Sample 4 & 27.3940 & 0.031691 & 1.332200 & 0.112820 \\
\hline
\end{tabular}

\section{Results and discussion}

The properties of PES filament yarns and the applied test method are shown in Table 3, whereas the properties of test fabrics and the applied test method are shown in Table 4.

The changes in the surface mass of fabrics during washing (up to 50 washing cycles) are presented in Table 5 , whereas the changes in the water vapour resistance of fabrics (Ret values) and test conditions are presented in Table 6.

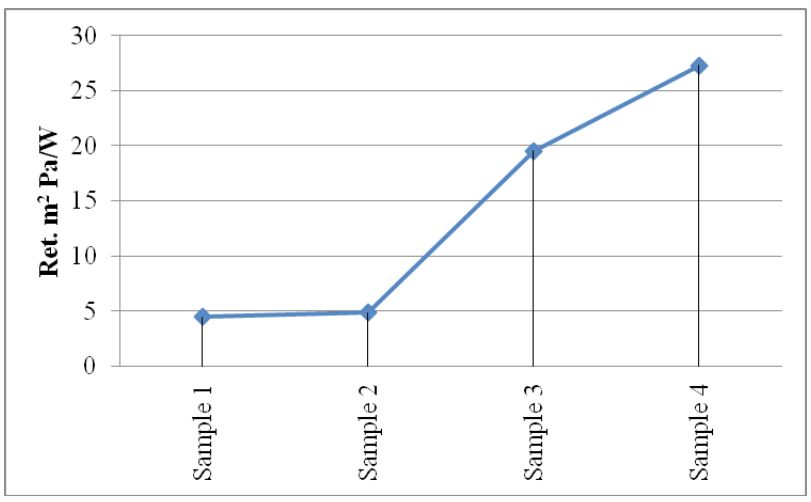

Figure 2. Ret values of untreated fabrics (sample 1-4)

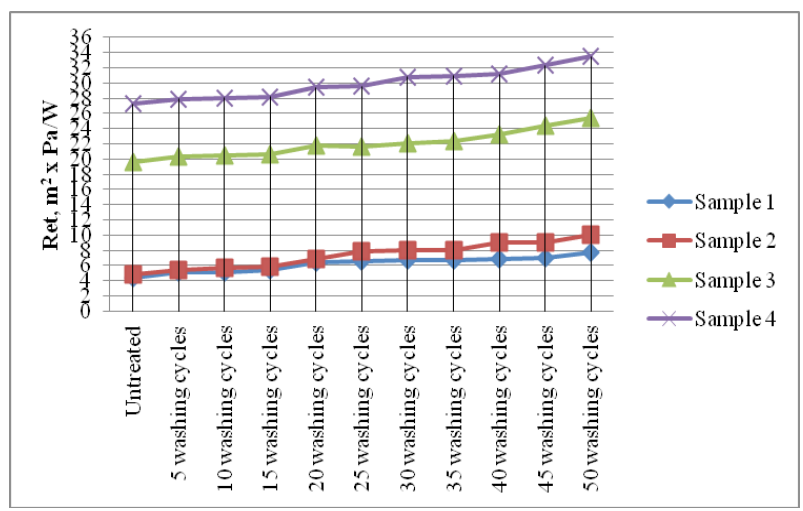

Figure 3. Ret values of fabrics up to 50 washing cycles (samples 1-4)

Figure 2 shows Ret values of the four untreated fabrics (samples 1-4). Sample 1 has the lowest water vapour resistance, since it is a basic non laminated fabric. Sample 2, laminated with PTFE membrane, has very similar Ret values as sample 1. The reason is the PTFE membrane structure which is water vapour highly permeable. Sample 4 has the highest Ret value which, being a three-layered fabric, was expected. The third layer is a knit that gets shaggy and swollen in the finishing process, reducing in that way the water vapour permeability.

Based on the obtained results, and according to Standard CEN/TR 16422:2012 - Classification of thermoregulation properties [8], the classification of fabrics (samples 1-4) can be done in the following way:

Protection levels of a middle-layer material, warm environment:

Class A (very good): none (Ret < 3 )

Class B (good): none (Ret < 4)

Class C (acceptable): samples 1 and 2 (Ret < 5)

According to this classification, samples 3 and 4 do not meet the criteria, which means these fabrics are not suitable for wearing in the warm environment. Having in mind the PU membrane properties and the presence of a knit in the third layer in sample 4 , it can be concluded that clothing made of these fabrics would be too hot and uncomfortable to wear in the warm environment.

Figure 3 shows Ret values of fabrics at different numbers of washing cycles. For all samples, it can be noticed that the water vapour resistance (Ret) is increasing with the increase of the number of washing cycles. Sample 4 has the highest Ret value and sample 1 has the lowest Ret value. Since sample 4 is a three-layered fabric, the basic layer and the knit are subject to shrinking which leads to the decreased diffusion of the water vapour through the fabric, that is, to the increase in the water vapour resistance. Samples 2 and 3 have lower Ret values.

These fabrics are two-layered and laminated which is the exact cause of the changes that occur during washings. Namely, while being washed, the membranes suffer certain changes in the structure, when their water vapour permeability quality declines and Ret values increase. Also, it can be noticed that the results of the samples 1 and 2 are very similar, which has to do with the smallest difference in the surface mass. The PU membrane in itself has bigger surface mass than the PTFE membrane, and adhesives applied in the process of lamination make sample 3 all heavier.

The washing process causes an insignificant decrease of the fabric surface mass. As a result of washing, the changes in the fibers structure of the fabrics made of $100 \%$ PES occur. PES fiber becomes deformed (both from the inside and the outside), and a gap in the material structure is filled out. The fiber gets curly, and the effect gets stronger with the increase in the number of washing cycles (Table 5). 


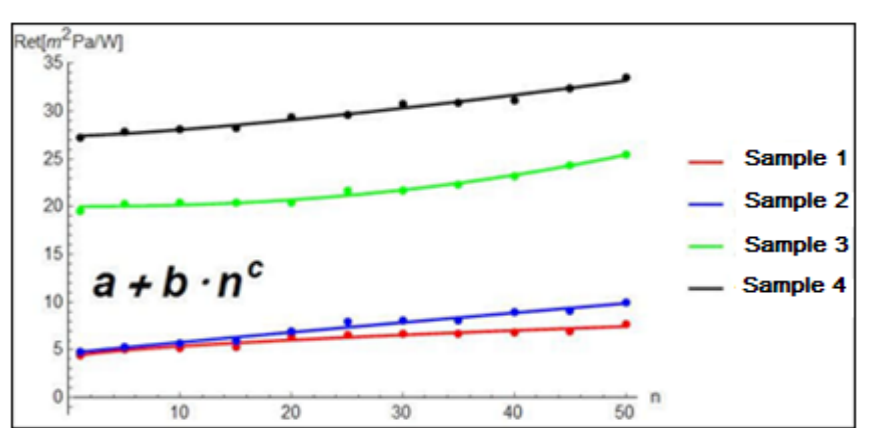

Figure 4. Overview of the functional dependence of Ret values on the number of washings of the fabric samples

Functional dependence of Ret values of samples 1 to 4 on the number of washing cycles

The obtained results of experimental tests of Ret with respect to the number of washing cycles are approximated by a non-linear model of fitting the data in the form:

Ret $=a+b \cdot n c(3)$

where $a, b$ and $c$ are constants that have to be determined so as to obtain local and optimal matching with the given data (this property is stressed due to the fact that linear models require global matching with the data), whereas $\mathrm{n}$ is an independent variable, i.e. the number of washings the sample is subjected to.

The experimental data show that the results comply the gradational function, and that their initial value is "untreated", which is why a modified gradational mathematical model was used for approximation purposes where modification is reflected in adding the constant $a$.

Table 7 provides a breakdown of calculated coefficients of the empirical formula and a breakdown of $S$ values for changes in the Ret value with respect to the number of washings of the observed fabric samples. Since S values are very small for all samples, it can be concluded that empirical formulae which illustrate the functional dependence of Ret values on the number of washings properly fit the experimental data for all samples, and that the proposed mathematical model can be applied to similar fabrics.

Joint overview of all the data obtained by measurements and a polynom with which they were approximated for different values of $a$ and $b$ constants and an exponent $\mathrm{c}$ are presented in Figure 4.

\section{Conclusion}

Based on the analysis, comparison and statistical processing of the obtained results relating to the thermos physiological property of materials - water vapour resistance, the following can be concluded:

- For the quality depiction of the properties of thermos-physiological comfort of textile products, a systematic approach has to be applied. This approach includes measurement and calculation of a number of parameters relating to yarn-fabric-processingclothing item sequence. In order to reach certain conclusions with greater certainty, the influence of parameters was observed per groups instead of individually, using carefully designed and manufactured fabric samples. The conducted tests indicate that certain properties of yarns and fabrics significantly affect the change in the water vapour resistance of the fabrics. Out of the yarn parameters, the important ones are the longitudinal mass, number of turns (twist), length of fibers in the yarn and raw materials composition, whereas the surface mass, thickness and density of threads are important fabrics parameters. The fabrics structure needs to be pointed out in particular, because of the great influence on other physical-mechanical and thermophysiological properties of all fabrics.

- Tracking of the changes in fabrics properties during washing cycles (up to 50 washing cycles) shows an insignificant decrease in the surface mass.

- The proposed mathematical models of the functional dependence of thermophysiological properties (Ret) on the number of washings during usage of the clothing item (fabric) properly fit the experimental data and can be applied to similar fabrics. These models can be used to predict the behaviour of the clothing made of these fabrics while being cared for while in use, which can be a significant factor when choosing materials for the production of a specialpurpose clothing item.

The conducted tests and presented results will help to predict comfort parameters of similar clothing items and to assess their usage properties.

\section{References}

[1] J. Huang, Review of heat and water vapour transfer through multilayer fabrics, Textile Research Journal, 86(3) (2016) 325-336.

[2] M. Farzandi, S. Razipour, F. Mousazadegan, S. Saharkhiz, Effects of using interlinings on physical and mechanical properties of wind stoppers, International Journal of Clothing Science and Technology, 25(2) (2013) 99 - 108.

[3] H. Park, S-k. Hwang, J-Y. Lee, J. Fan, Y. Jeong, Impact of electrical heating on effective thermal insulation of a multi-layered winter clothing system for optimal heating efficiency, International Journal of Clothing Science and Technology, 28(2) (2015) $254-264$.

[4] ISO 11092:2014 -Textiles -- Physiological effects Measurement of thermal and water-vapour resistance under steady-state conditions (sweating guarded-hotplate test)

[5] J.T.Williams, Textiles for Cold Weather Apparel, Woodhead Publishing in Textiles, 2009, p. 159.

[6] D. Herceg, N. Krejić, Numerička analiza, Univerzitet u Novom Sadu, Stylos, Novi Sad,1997, p. 33-71

[7] G. V. Milovanović, Numerička analiza, (I deo, II deo, III deo), Naučna knjiga, Beograd, 1985, p. 10-118

[8] CEN/TR 16422:2012 - Classification of thermoregulation properties

[9] ISO 1833-1:2006 -Textiles -- Quantitative chemical analysis -- Part 1: General principles of testing 
[10] SRPS EN ISO 2060:2012 -Textiles -- Yarn from packages -- Determination of linear density (mass per unit length) by the skein method

[11] SRPS ISO 2061:2012 -Textiles -- Determination of twist in yarns -- Direct counting method

[12] ISO 1833-24:2010 -Textiles -- Quantitative chemical analysis -- Part 24: Mixtures of polyester and certain other fibres (method using phenol and tetrachloroethane)

[13] ISO 3801:1977 -Textiles -- Woven fabrics -- Determination of mass per unit length and mass per unit area

[14] ISO 5084:1996 -Textiles -- Determination of thickness of textiles and textile products

[15] ISO 7211-2:1984 - Textiles -- Woven fabrics -- Construction -- Methods of analysis - Part 2: Determination of number of

\section{PROMENA OTPORNOSTI MATERIJALA ZA IZRADU ODEĆE PROLAZU VODENE PARE TOKOM EKSPLOATACIJE}

Mirjana Reljić ${ }^{1}$, Jovan Stepanović ${ }^{2}$, Branislava Lazić ${ }^{3}$, Nenad Ćirković ${ }^{2}$, Dragana Cerović ${ }^{3}$

${ }^{1}$ Cis Institut, Beograd, Srbija

${ }^{2}$ Tehnološki fakultet, Univerzitet u Nišu, Leskovac, Srbija

${ }^{3}$ Visoka tekstilna strukovna škola za dizajn, tehnologiju i menadžment, Beograd, Srbija

$\mathrm{U}$ radu su ispitivane promene termofizioloških svojstava tkanina nastale tokom održavanja, odnosno pranja odeće. Korišćena su merenja izvedena na vrućoj ploči. Rezultati ispitivanja nisu posmatrani pojedinačno nego kroz međusobne povezanosti svojstava materijala. Dobijeni rezultati pokazuju da određena svojstva pređa u velikoj meri utiču na promenu otpornosti tkanina prolazu vodene pare (Ret) i iskorišćeni su za uspostavljanje matematičkog modela za predviđanje termofiziološke udobnosti tkanih struktura pri upotrebi, odnosno nezi. Sprovedeno istraživanje omogućilo je opis, klasifikaciju i definisanje elemenata povezanosti između parametara tkanina sa termofiziološkim svojstvima odevnog predmeta, na osnovu kojih se mogu predvideti parametri udobnosti sličnih tkanina, kao i upotrebna svojstva proizvoda izrađenih od njih.
(ORIGINALNI NAUČNI RAD) UDK 687:677.07

Ključne reči: tekstilni materijali, otpor prolazu vodene pare, vruća ploča, toplotna udobnost odeće 